\title{
Defoe's The Storm as a model for contemporary reporting
}

Chapter 1 in Keeble, R. and Wheeler, S. (2008) The Journalistic Imagination. Literary Journalists from Defoe to Capote to Carter, Abingdon, UK, and New York: Routledge

\section{Jenny McKay}

Daniel Foe was born into a family of a successful tradesman in 1660. As a young man he went into business too, dealing at various times in meat, hosiery, wine, tobacco, perfume, horses and bricks, often with disastrous results such as bankruptcy and imprisonment in 1692 and 1703. Defoe married in 1684 and was the father of at least six children, one of whom became a journalist, although without notable success. Foe added the prefix De to his name in 1695, perhaps, as some have speculated, to enhance his social standing by the adoption of a name that sounds more aristocratic (Richetti 2006: 19). He was educated at the Nonconformist Morton's Academy, renowned for its forward-thinking approach to education which stressed science, economics and modern rather than classical languages. Defoe acquired a strong interest in politics and social affairs as well as religion, at a time when deep divisions separated Catholic from Protestant in all aspects of life including the accession to the throne. Along with his business activities Defoe held public office but by the 1690s he was establishing himself as an energetic and eloquent writer of political, religious and moral polemic and satire. This got him into trouble with the authorities for which the punishment was to stand in the pillory. From the early years of the eighteenth century Defoe depended on highlevel patronage for his livelihood and was employed as a propagandist and a secret agent charged with setting up an intelligence network by those in power, most notably Robert Harley, Earl of Oxford, MP, Speaker of the House of Commons, a Secretary of State 'and prime minister in all but name' (Downie 1979: 2). Defoe developed his extraordinary facility with words to become a writer of astounding productivity and invention. He is widely credited with a role in the foundation of at least two genres journalism and the novel, although his most famous fiction, Robinson Crusoe, was not written until 1719 when Defoe was nearly 60. He died in 1731, alone and impoverished. 
For someone who wrote so much there is surprisingly little known about his personal and domestic life.

Most people know Daniel Defoe as the writer of the novels Robinson Crusoe and Moll Flanders (1722). His renown as a novelist has long overshadowed his reputation as a journalist even though he was successful, prolific and innovative as a writer of factual as well as fictional narratives. When his journalism is considered by scholars it tends to be the polemical pieces about religion, morals, economics and politics. Or the journalism is used as a source of information by historians, especially those interested in politics or social issues. Much less often is the journalism studied in its own right as a subject for literary and textual analysis.

Why, then, is so little of Defoe's journalism read today even though it forms such a large proportion of his huge output? The most obvious reason is that journalism is considered ephemeral: it is by definition about current affairs. When Defoe was writing about the political and religious controversies of his time he could assume his audience knew the background and cared about the debate. Today's readers need specialized knowledge of the period to be gripped by some of Defoe's arguments. A second reason is that the quality and popularity of Defoe's novels mean readers may not think of looking beyond them. Then there is the question of canon-formation, of who gets to decide what is worthy of being read, studied or published. The English literature establishment is reluctant to accord literary status to journalistic writing, while much of the journalism establishment is equally reluctant to celebrate journalism for its literary merit. A kind of snobbery is partly to blame for this, which means that those who write for a living are looked down on as mere hacks and compared unfavourably with those whose motivation is thought to be the higher calling of the creative arts. Lastly, and partly for the reasons I've listed, there is the problem of access: the journalism of Defoe, like that of many other great writers, is not easy to find by readers who are not members of academic libraries.

Yet this neglect of Defoe's journalism is all the more surprising given the establishment in the academy in the UK over the past 30 years - and in the United States over more 
than a century - of the field of Journalism Studies. Here you might expect to find at least some of his vast journalistic output being read by students and lecturers keen to examine early examples of their own practices. In practice this hardly happens. This is to miss a great deal. ${ }^{1}$

\section{Defoe's vast journalistic range}

In addition to politics, Defoe wrote on a vast range of topics. A 'veritable writing machine', one recent biographer, John Richetti, calls him (2005: ix). Defoe wrote, argued, reported, and he edited. He founded his own magazine, the Review, and wrote it more or less single-handedly from 1704 to 1713, publishing three editions a week - an undertaking that included separate editions for Scotland where for some of that period he was based. For the Review he was a reporter, a political commentator, an agony uncle, a leader writer, a critic, a gossip columnist (or scandal-monger as the term then was) and, under the pen name Mr Review, was the precursor of the growing legions of writers of opinion columns. 'For sheer fluency and day-to-day pertinence and insight, there is nothing else in English political writing then or since quite like this extended and unflagging performance,' writes Richetti (ibid: 97).

He argued vigorously in favour of educating women. He wrote about the 1707 Act of Union with Scotland, about road maintenance, about insurance schemes and against the idea that there is any such thing as a pure-bred Englishman. The press, magic, family life, the servant problem, religion, usury, ghosts, language and diplomacy were other subjects he tackled. He offered practical advice to anyone who might be willing to listen: for example, when, in 1721, it seemed likely that the plague was again about to cross the Channel from Europe he sought to influence the thinking of officials about how such a crisis could best be prepared for and dealt with. In this case, typically, he produced articles as well as two books out of his material: the overtly didactic Due Preparations for the Plague in 1722 and a month later the work which would now be classed as a historical fiction, A Journal of the Plague Year.

This book has long been acclaimed for its sympathetic and dramatic reconstruction of the outbreak of plague in 1665 in London. Written with the cool objectivity of an 
observer, the narrative is convincing in its realism and it has, like Robinson Crusoe which was published three years later, acquired the significance of a literary archetype. ${ }^{2}$ A Journal of the Plague Year is the moving study of an individual and a society going through a period of intense crisis both tangible, in the disease, and intangible, in the moral dilemmas the outbreak poses. (La Peste, of 1947, by the French novelist and journalist, Albert Camus, is perhaps the best-known successor fiction.) However, the weight that this seriousness implies is not burdensome. The novel is richly textured, warm and humane, and shows a compassion for the suffering of the poor.

Unlike a significant proportion of Defoe's writing, A Journal of the Plague Year leaves no doubt as to whether he was the author. ${ }^{3}$ This is not true of all the works which have been attributed to him but even if you count only those texts about which his authorship is not in question, the range of his curiosity, the breadth of his knowledge, and his unflagging need to communicate with as many people as possible using language they could understand is remarkable. He was a fluent, opinionated, knowledgeable and versatile writer. These attributes are also, of course, a suitable description of those who would be most employable in the newsrooms of today, and this may help to explain the strength of his appeal for journalists of our time such as biographer Richard West, and the BBC's former political editor, Andrew Marr. According to West, Defoe was 'a great and not just a good reporter' (1997: 87). And for Marr, he was a 'writer of genuine genius' who created 'a journalistic style that lasted'. He wrote excellent, clear, uncluttered, reporterly English full of relatively short sentences of plain description' (Marr 2004: 8).

\section{The Storm: landmark text in development of British journalism}

Fortunately some of Defoe's journalism and other non-fiction writing is now in print, most notably one of his earliest works, The Storm. For modern readers this provides a welcoming route into the journalistic writing of "one of the most significant figures in the history of print journalism' (Ellison 2006: 91). It does not depend on much background knowledge as it is about a severe weather event, which readers can relate to their own experience. As a nation the British are known for their obsession with the weather and with disastrous-weather stories in particular: they like to hear about the 
physical damage to cities and countryside, about destruction, miraculous escapes, tragic deaths, about acts of bravery contrasted with acts of calculating cruelty. They like to apportion blame for what has gone wrong. ${ }^{4}$ All of these are tropes with which modern journalists and their readers are familiar. And Defoe's The Storm offers all of them in a book which, by virtue of its publication date, can be seen as a landmark text in the development of British journalism and the writing of popular narrative.

It was written at a time when what we would now call journalism (but for which there was then no single collective term) was flourishing. After a period of tight government control over what was published the Licensing Act was allowed to lapse in 1695 in England and this unleashed a torrent of news publishing in new forms and by new writers (Smith 1979: 45-47, 56). The first recognizable newspaper, the Daily Courant, appeared in 1702, the first women's magazine, the Ladies' Mercury, and many other titles were to follow in the first decades of the eighteenth century. By the 1690s Defoe was already gaining a reputation, notoriety even, as a pamphleteer, and as his business activities became more calamitous he found himself poised to play a full part in the what Ellison describes as 'a proliferation of texts and the expansion of . . . communication systems' which is unique in the history of the media (2006: 2).

One example of his activities is The Storm: or, a Collection of the most remarkable Casualties and Disasters which happen'd in the Late Dreadful Tempest, both by Sea and Land, to give its full title, which was published in 1704, 'printed for G. Sawbridge and sold by J. Nutt' (Hamblyn 2003:1). It commemorated what remains the worst tempest ever recorded in the British Isles. The wind had swept across southern England for a week in late November 1703, destroying thousands of buildings, felling millions of trees, as well as killing thousands of people including a fifth of the sailors in the British Navy. Little wonder that the monarch, Queen Anne, described it as 'a Calamity so Dreadful and Astonishing, that the like hath not been Seen or Felt in the Memory of any Person Living in this our Kingdom' (ibid: xxxix). It is also likely that Defoe, who had recently emerged from debtors' prison and who had a family to support, recognized in the event a way of earning some much needed money by using his writing skills. For most of his adult life until this storm, Defoe had earned his living from commerce 
although during the 1690s he was also forging a career as a writer of poetry, journalism and polemical pamphlets.

The Storm is not a novel. Its first-person authorial voice states that it is based on true accounts of what happened during and just after the hurricane, eyewitness accounts solicited from all over the country by means of advertisements in the London Gazette, which was founded in 1666 as an official government newspaper carrying mainly foreign news, and the Daily Courant, the first English daily newspaper, founded in 1702. Here is part of the advertisement:

To preserve the Remembrance of the late Dreadful Tempest, an exact and faithful Collection is preparing of the most remarkable Disasters which happened on that Occasion, with the Places where, and Persons concern'd whether at Sea or on Shore. For the perfecting so good a Work, 'tis humbly recommended by the Author to all Gentlemen of the Clergy, or others, who have made any Observations of this Calamity, that they would transmit as distinct an Account as possible, of what they have observed (London Gazette 3975, 13-16 December 1703).

The advertisements can still be viewed in newspaper archives, as can other documents such as Philosophical Transactions, the journal of the Royal Society (the learned society of scientists founded in 1660), on which Defoe drew for some of his research and from which he quotes in The Storm. ${ }^{5}$ He refers to other traceable documents, as well as to the letters his advertisement elicited from clergymen, gentlemen, 'honest countrymen', an apothecary, sailors and even one woman, who were scattered throughout the large area of England devastated by the storm. By this means Defoe seeks to establish the authenticity of the events and scenes he describes. ${ }^{6}$ He developed this technique in his later narrative writing even when it is not a factual account. $A$ Journal of the Plague Year is one example where he makes extensive use of documents such as the Bills of Mortality (lists of the names of those who died and the causes of death) from London churches to help to establish the authenticity of what he describes within a fictional account of an event which had in fact taken place. 
Like A Journal of the Plague Year, The Storm describes a society in the grip of catastrophic events which will have lasting effects both physical and psychological on the people who witness them. The order of magnitude may be different (the 1703 storm left around 8,000 dead, the plague in 1665 around 97,000) but a reading of both suggests a connection between the way the narratives were conceived by Defoe: it is hard to believe that his fictional account of London's plague would have been written in the same way if The Storm, a largely factual account, had not appeared first. The Storm was Defoe's first full-length book and in it we see him experimenting with ways of writing about experience which are later developed in his fictional narratives. One example is the use of eyewitness accounts. For The Storm these are gathered from the author's correspondents and contacts, to use the journalists' jargon of today. In his novels such as A Journal of the Plague Year the viewpoints of imagined 'eyewitnesses' are regularly used to narrate events, although it is probable that he had heard accounts directly from people who lived through the plague in London in 1665.

The Storm, then, is worth reading both for its own sake and for its significance as a founding text for both journalism and the novel. The journalist and biographer of Defoe, Richard West, argues that as a piece of reporting The Storm is 'a masterpiece, which puts to shame all modern accounts of disaster whether in books, newspapers, radio or television' (1997: 86). During what turned out to be 'the golden age of journalism' in the early eighteenth century, Defoe was 'the first master, if not the inventor, of almost every feature of modern newspapers' (ibid: xiii). One of Defoe's main strengths, in West's eyes, was that 'he excelled in the art of telling a story', just as Richard Hamblyn, editor of the modern edition of The Storm, praises Defoe for his 'narrative instinct' (2003: xxvii).

\section{Early master of modern journalism}

West's suggestion that Defoe was an early master of modern journalism is easy for us to test, as the daily round of hard news production in our increasingly frenetic media age supplies us with many examples of disaster reporting, some of them offering direct parallels with Defoe's approach. Here are two quotations from people who lived through severe storms of wind but are separated in time by 300 years. The first is from 
The Storm, the second is an eyewitness quoted on the BBC news website, after a more modest gale.

Several hundred of Apple-Trees and other Trees blown down: Most Houses damnify'd in the Tiles and Thatch ... Our loss in the Apple-Trees is the greatest; because we shall want Liquor to make our Hearts merry (Defoe 2003: 97).

'Last weekend I thought I must prune the apple tree this autumn. Well no need to do that now - the wind blew it over. I don't know what has upset me more the fact that the tree has blown over or the realisation that my annual intake of apple-pie will be seriously reduced this year.' (BBC news website ${ }^{7}$ )

This endearing preoccupation with apple-trees and consequent dismay about apple deprivation is the kind of detail which, as any journalist knows, brings a story to life. Andrew Marr, another of Defoe's journalist admirers as we have seen, praises Defoe for his understanding of the importance of developing trust between journalists and their readers and also for being a reporter who believed in seeing and hearing things for himself (2004: 9). For Anthony Burgess, Defoe, in his absolute 'devotion to the craft of reportage', (1966: 12) was 'our first great novelist because he was our first great journalist', (1966: 7). Burgess is drawing attention here to Defoe's contribution to the development of realism as a literary convention and noting the links between this development and early attempts by journalists including Defoe to make a literary record of reality. The Storm represents, at around 75,000 words, the first recognizable piece of modern journalistic reporting and book-length features journalism of a sort that is still, and increasingly, practised in English as well as other languages. It was the eighteenthcentury equivalent of an instant book and was published within seven months of the disaster.

The idea of writing about this storm was not Defoe's alone. There are other accounts of it as well as of other momentous events stretching back through the seventeenth century. One example is The Wonders of this windie winter, which was published in 
1613 (Hunter 1990: 178-179). Other periodicals carried brief accounts within a few days and the January and February 1704 edition of the Royal Society's journal, Philosophical Transactions, was, as Hamblyn observes, almost a storm special: three out of that edition's eight contributed letters were about the hurricane and a further one was about the earthquake which may or may not have been related to it (2003: xxxi).

Defoe offers these letters as some of several documentary sources of information he uses to compile his own narrative. Of those who died, more than 1,100 were stranded on Goodwin Sands in the English Channel. One ship was blown from there, in the south of England, all the way to Norway. Defoe revelled in detail whatever his subject. For The Storm he presents scientific explanations and shows evidence of his research into the records of barometric pressure on the days before and after the storm struck, as sent to the author by a Mr Derham. He also presents the documentation relating to the terrible loss of life among sailors. His irrepressible and admirable drive to improve and manage things is shown by his inclusion of a table illustrating how sailors refer to the various strengths of wind: he then proceeds to set up his own table of wind strengths to make the measurement clearer. His table anticipates the establishment of the Beaufort scale by around a hundred years.

\section{Pioneering example of human-interest story}

But it is as an early example of the journalistic human-interest story that The Storm is most compelling for today's readers. It is a record of narrow escapes and loss of life. The Bishop of Bath and Wells was killed along with his wife:

...by the Fall of two Chimney Stacks, which fell on the Roof, and drove it in upon my Lord's Bed, forced it quite through the next Flower [floor] down in the Hall, and buried them both in the Rubbish: and 'tis suppos'd my Lord was getting up, for he was found some Distance from my Lady who was found in her Bed (2003: 71). In addition:

- Defoe records massive damage to property. He says he saw 17,000 trees down in the county of Kent alone before he stopped counting. In St James's Park 'above 
a Hundred Elms' were blown over, some having been planted in the sixteenth century. In Gloucestershire one gentleman had:

'many Woods; among which was one Grove of very tall Trees, being each near Eighty Foot high; the which he greatly valued for the Tallness and Prospect of them, and therefore resolv'd never to cut them down: But it so happen'd that Six Hundred of them within the Compass of Five Acres were wholly blown down' (ibid: 71).

- It's a record of cowardice, selfishness and inhumanity as shown by the townspeople of Deal who could see sailors trapped on the Goodwin Sands but for whom they could neither find boats to rescue them nor any help once they were saved (ibid: 134).

- Defoe is at pains to celebrate heroism, self-sacrifice and generosity as shown by the Mayor of Deal. Infuriated by his townspeople's selfishness, he took boats by force to rescue several hundred men and paid from his own pocket for food and shelter for the wretched survivors. In a passage which has a certain understandable testiness about it, Defoe describes how the government was at first unwilling to help with the travel costs home for these men who were, after all, employed by the British Navy when their ships went down (ibid: 134-136).

- And it's a record of comical moments such as the story of the itinerant woman, offered lodging in a barn for the duration of the storm, who found in the morning that her all clothes, hung up to dry out, had been blown away during the night along with the roof of the barn. She had to climb out almost naked through the rafters (ibid: 77).

This kind of anecdote is familiar to modern consumers of news media but when Defoe was writing it was not the norm. Literary historian J. Paul Hunter notes that it was a relatively new phenomenon in the late seventeenth century for people to be so interested 
in the immediate and the contemporaneous and he ascribes this to a growing interest in discovery, enlightenment, and novelty (1990: chapter 7).

\section{Verification and reliability of sources}

Such immediacy raises questions about sources and the reliability of testimony, questions which were on Defoe's mind too. As narrator of The Storm he says he can't personally verify every letter he presents. Where he can't, he publishes anyway but with a warning that it is second-hand testimony. In his 'Preface' he is at pains to establish the credibility of what he writes, explaining that writers carry a responsibility to posterity for the accuracy of their work:

If a Book Printed obtrudes a falsehood, if a Man tells a Lye in Print, he abuses Mankind, and imposes upon the whole World, he causes our Children to tell Lyes after us, and their Children after them. . (2003: 3).

He condemns earlier 'Pen-men' whose 'prodigious Looseness of the Pen has confounded History and Fable from the beginning of both' (ibid: 5) and seeks to distance himself from such 'ridiculous Stuff' as the Greek myths, proclaiming his own desire to 'keep close to the Truth' (ibid: 8). He is aware of the responsibility he carries: 'I have not undertaken this Work without the serious Consideration of what I owe to Truth, and to Posterity' (ibid: 5).

This leads him to explain why there is such variety in the writing style of the accounts he presents in his book. He makes 'Apology for the Meanness of Stile' of some of his correspondents and for reproducing it without alteration. Of one, he says the style is:

Coarse, and Sailor like; yet I have inserted this Letter, because it seems to describe the Horror and Consternation the poor Sailors were in at that time. And because this is Written from one, who was as near an Eye Witness as any could possibly be, and be safe (ibid:131). 
Defoe is arguing that 'The Plainness and Honesty' of his witnesses' stories is more important than any lack of literary sophistication (ibid: 8). Defoe came from a family of religious Dissenters and was, therefore, not educated at a university where emphasis was laid on traditions of rhetorical writing based on classical models. Defoe's own education, at the Dissenters Academy in Newington Green, London, was strongly influenced by the Baconian tradition of intellectual inquiry which had led to the formation of the Royal Society in the 1660s. In her book Defoe and the New Sciences, Ilse Vickers (1996) describes how seventeenth-century precepts about language are demonstrated in Defoe's work: everyday, simple language without decoration or flourish was to be preferred as the most effective means of communication and, therefore, as the best way to contribute to the advancement of knowledge. ${ }^{8}$

This tenet is relevant to journalistic writing today and a look at any current journalism textbook reveals links between late seventeenth-century Plain Style and the way journalists are now taught to write. Here's one example from countless: 'What is needed is plainness, decorum, economy, precision - above all clarity. What is not needed is rhetoric or embellishment' (Hicks 1999: 124). Defoe strove to write clearly and simply and encouraged others to do the same, notably in the introduction to The Complete English Tradesman (1726-1727), a book aimed at young men at the start of careers in business. For advice about writing style many British journalists nowadays are able to refer back to the influential essay by George Orwell, 'Politics and the English language', of 1946, in which he encourages all writers to strive for brevity, clarity and freshness of expression while railing against pomposity, euphemism and cliché. But how many know about earlier attempts to manipulate language written and spoken, even though these have a significant place in the history of journalistic writing?

\section{Echoes of Defoe's journalism in current practice}

Vickers's book describes other ways in which Defoe's methods have echoes in our current journalism practice. For example, she draws attention to the emphasis placed by the 'New sciences' on observation and the collection and classification of information

gathered at first hand, on empirical enquiry, on accuracy, and on sceptical questioning as a habit of mind (1996: 65). And as Robert Mayer argues, The Storm exemplifies the 
way in which 'the "scientific" methodology of the new history' could be used to create a work that 'depends heavily upon narrative and is intended to have popular appeal' (1997: 162).

In keeping with these principles Defoe's descriptions are made vivid by his own colloquial writing style and by the evidence he offers that he was there, right in the middle of the terrible event which is the subject of his book:

The Author of this Relation was in a well-built brick House in the skirts of the City; and a Stack of Chimneys falling in upon the next Houses, gave the House such a Shock, that they thought it was just coming down upon their Heads: but opening the Door to attempt an Escape into a Garden, the Danger was so apparent, that they all thought fit to surrender to the Disposal of Almighty Providence, and expect their Graves in the Ruins of the House, rather than to meet most certain Destruction the open Garden. . . the Author of this has seen Tiles blown from a House above thirty or forty Yards, and stuck from five to eight Inches into the solid Earth' (2003: 30$31)$.

\section{The reporter as eye-witness}

This desire to 'be there' is a strong motive for all the best writers of journalism, an idea that will be familiar to those who have trained as newspaper reporters. Andrew Marr argues for the importance of journalists getting out of their newsrooms to go and report. So does Tom Wolfe in his essay 'The New Journalism' in which he praises feature writer Jimmy Breslin for his insistence on being able to 'leave the building, go outside and do reporting on his own, genuine legwork'. And John Carey, not a journalist but an literary critic, academic and anthologist of journalism explains that reportage is at its strongest when it is based on eyewitness accounts, when it 'derives ultimately from people who can says "I was there"' (Marr 2004: 384, Wolfe 1973: 25, Carey 1986: xxix).

In The Storm we encounter Defoe in an early demonstration of the role of the eyewitness reporter during and immediately after a disaster, out and about in the streets, 
dodging danger (in this case flying roof tiles) as he talked to people. He asked, he observed, he counted, he made projections from the statistics, and he apportioned blame. That's very much what journalists do today. So too is adding up the cost translating the human and physical disaster into money terms as a way of conveying to readers the impact of what has happened.

Indeed the City was a strange Spectacle the Morning after the Storm, as soon as the People could put their heads out of Doors ... The Streets lay so covered with Tiles and Slates, from the Tops of the Houses, especially in the Out-parts, that the Quantity is incredible: and the Houses were so universally stript, that all the Tiles in Fifty Miles round would be able to repair but a small Part of it.

Something may be guest at on this Head, from the sudden Rise of the Price of Tiles; which rise from 21s. per Thousand to 61 . for plain Tiles; and from 50s. per Thousand for Pantiles, to 10 1. and Bricklayers Labour to 5s. per Day (ibid: 57). ${ }^{9}$

Defoe gathered quotes to bring his story alive. In this case, as we have seen, he sought written quotations from correspondents throughout the country. (This is a good example of the Baconian method for gathering scientific data being applied to create a journalistic record.) Journalists still advertize for informants through the media. Modern reporters still construct their stories from quotations, especially from eyewitnesses in the case of big events, but also when comments are needed.

Defoe uses his carefully gathered range of points of view to engaging effect in The Storm and his assertion that nothing can be more useful to 'the publick services than plain, naked, and unbyasst accounts both of persons and things' is at once Baconian and a useful summing up of what the better journalists try to do today, even if there is now a certain scepticism about how far the stories they write can ever be free of bias. Journalism is sometimes mocked for its pretensions to being, and inadequacies as, a first draft of history but to make a contribution to the historical record of his time was one of Defoe's motivations in writing The Storm and there is no doubt that he succeeded in constructing, as Ellison describes, 'a collective memory of the event' by drawing together 'multiple narratives of personal suffering' (Ellison 2006: 107). 
Defoe also provides background information based on his own reading to put events into context, to try to explain, in this case, how winds in general occur and what might have caused this one in particular. For this he offers religious as well as scientific explanations. To take religion first:

The main inference I shall pretend to make or at least venture the exposing to publick View, in this case, is, the strong Evidence God has been pleas'd to give in this terrible manner to his own being, which Mankind began more than ever to affront and despise ... I cannot doubt but that the Atheist's hard'ned Soul trembl'd a little as well as his House' (ibid: 7).

Besides arguing that the storm was sent by God to show atheists that he did, in fact, exist, Defoe suggests the storm is a punishment for wickedness, describing it as 'the dreadfulest and most universal Judgment that ever almighty Power thought fit to bring upon the Part of the World' (ibid:9).

Religious explanations do not, however, preclude scientific ones. Against any readers who might see a contradiction in looking to God as well as to the laws of physics for explanations, Defoe argues that 'a Philosopher [we would now say scientist] may be a Christian, and some of the best of the Latter have been the best of the Former (2003: 13). Chapter 1 is called 'Of the Natural Causes and Original of Winds' and in it Defoe recounts late seventeenth-century scientific thinking about the physical causes of winds, while proposing that God may have had an overarching purpose in sending this particular one.

\section{Defoe's modernity}

The Storm is a fascinating narrative because of the way Defoe pieces together recent tragic events of great social and personal significance and then tells the story as fully as he can. Practices we now take for granted in journalistic research and narration were part of Defoe's method: how research is conducted; how testimony is gathered and used; which news values inform the selection of material; the role in the narrative of the 
eyewitness and the expert; how the writer tries to establish the authenticity of his account; how blame is apportioned; and, not least, what kind of language is used to write up the material.

It can be seen as a milestone in the development of both journalism and the novel. This is to emphasize the strength of the link between two different kinds of realism: between writing which claims to present verifiable reality (journalism) and writing which aims to present invention as if it were reality (realist fiction). For anyone interested in the history of journalistic writing The Storm contributes to an understanding of how such writing came to be as it is and what it can achieve. For anyone interested in the history of literature The Storm contributes to an understanding of how the conventions of realist fiction began to be developed. For these reasons, in addition to its intrinsic interest as an account of an unfolding tragedy, and for its significance as an early, experimental narrative by a writer revered as one of the English language's greatest writers, The Storm is a text well worth reading.

\section{Notes}

${ }^{1}$ The situation in the United States is better and improving, partly because there is a longer tradition of studying journalism in universities. However, as Hartsock explains, there remains a bias against journalism among English Studies specialists, while in journalism and mass communications departments the 'literary' aspect of journalism is still marginalized (Hartsock 2000: 6).

${ }^{2}$ Robert Mayer calls Crusoe 'a central text of Western civilisation' (1997:1).

3 The most definitive list of Defoe's writings is by P. N. Furbank and W. R. Owens (1998). Their 44-volume edition of Defoe's works is under way (2000-2008), published by Pickering and Chatto.

${ }^{4}$ Tom Fort's book Under the Weather (2006) bears this out and Kate Fox's chapter 'Weather' in Watching the English (2005) discusses this phenomenon from the respective perspectives of a historian and a social anthropologist.

${ }^{5}$ London Gazette 3972, December 2-6, 1703 and Daily Courant 409, December 2, 1703. Philosophical Transactions No. 289 p. 1530. 
${ }^{6}$ There are letters of doubtful origin. In particular the one purporting to be from a sailor still stranded on a ship in the English Channel (Hamblyn 2003: xxxi).

${ }^{7}$ http://newsvote.bbc.co.uk/mpapps/pagetools/print/news.bbc.co.uk/1/hi/uk/3875699.stm accessed on July 8, 2004

${ }^{8}$ Vickers further argues that The Storm is 'the work in which Defoe first explicitly declared his adherence to the principles of Baconian science' (1996:117)

${ }^{9}$ It's poignant to note that Defoe's main occupation before 1703 was as a man of commerce, albeit one whose businesses had a habit of going bankrupt. It had happened a few months before the storm - the business in question being the manufacture of roof tiles!

\section{References and further reading}

Brayne, M. (2002) The Greatest Storm: Britain's Night of Destruction, November 1703, Stroud: Sutton

Burgess, A. (1966) Introduction in Defoe, D. [1722] A Journal of the Plague Year, Burgess, A. and Bristow, C. (eds) London: Penguin

Carey, J. (1987) The Faber Book of Reportage, London: Faber and Faber

Defoe, D. (2003) [1704] The Storm (ed.) Hamblyn, R., London: Allen Lane, and (2004) Penguin

Defoe, D. (1726-7) The Compleat English Tradesman, London: printed for Charles Rivington

Defoe, D. (1997) The True-Born Englishman and Other Writings, (eds) Furbank, P.N. and Owens, W.R., London: Penguin

Downie, J.A. (1979) Robert Harley and the press: Propaganda and Public Opinion in the Age of Swift and Defoe, Cambridge: Cambridge University Press

Ellison, K. (2006) Fatal News. Reading and Information Overload in Early EighteenthCentury Literature, London: Routledge

Fort, T. (2006) Under the Weather: Us and the Elements, London: Century Fox, K. (2005) Watching the English: The Hidden Rules of English Behaviour, London: Hodder and Stoughton 
Furbank, P. N. and Owens, W. R. (1998) A Critical Bibliography of Daniel Defoe, London: Pickering and Chatto

Furbank, P. N. and Owens, W. R. (2006) A Political Biography of Daniel Defoe, London: Pickering and Chatto

Hamblyn, R. (2003) ‘Introduction', in Defoe, D. (2003) The Storm, London: Allen Lane and (2004), London: Penguin

Hartsock, J.C. (2000) A History of American Literary Journalism. The Emergence of a Modern Narrative Form, Amherst: University of Massachusetts Press

Hicks, W. (1999) Writing for Journalists, London: Routledge

Hunter, J. P. (1990) Before Novels: The Cultural Contexts of Eighteenth Century

English Fiction, New York and London: W. W. Norton and Company.

Marr, A. (2004) My Trade: A Short History of British Journalism, London: Macmillan. Mayer, R. (1997) History and the Early English Novel: Matters of Fact from Bacon to Defoe, Cambridge: Cambridge University Press

Novak, M. E. (2001) Daniel Defoe: Master of Fictions, Oxford: Oxford University Press

Orwell, G. (1946) Politics and the English Language, in Orwell, S. and Angus I. (eds) (1993) The Collected Essays, Journalism and Letters of George Orwell, Volume IV, London: Secker and Warburg pp 156-169

Payne, W. L. (1951) The Best of Defoe's Review: An Anthology, New York: Columbia University Press

Richetti, J. (2005) The Life of Daniel Defoe, Oxford: Blackwell Smith, A. (1979) The Newspaper: An International History, London: Thames and Hudson

Sutherland, J. (1986) The Restoration Newspaper and its Development, Cambridge: Cambridge University Press

Vickers, I. (1996) Defoe and the New Sciences, Cambridge: Cambridge University Press

Watt, I. (1957) The Rise of the Novel: Studies in Defoe, Richardson and Fielding, London: Chatto and Windus 
West, R. (1997) The Life and Strange Surprising Adventures of Daniel Defoe, London: HarperCollins

Wolfe, T. (1973) The New Journalism in Johnson, E. W. and Wolfe, T. (eds) The New Journalism, London: Picador pp 15-68 